ISSN 0258-7122

Bangladesh J. Agril. Res. 39(1): 59-66, March 2014

\title{
PERFORMANCE OF DIFFERENT PROTOCOLS ON IN VITRO TUBERIZATION IN POTATO (Solanum tuberosum)
}

\author{
M. ZAKARIA ${ }^{1}$, M. M. HOSSAIN ${ }^{2}$ \\ M. A. KHALEQUE MIAN ${ }^{3}$ AND T. HOSSAIN ${ }^{4}$
}

\begin{abstract}
Five protocols of micro tuberization were used to induce large size microtuber in three recommended potato varieties, namely Cardinal, Diamant, and Heera under complete dark condition. Tuberization was the earliest (11.8 days) in the protocol $\mathrm{P}_{2}(\mathrm{MS}+5 \mathrm{mg} / \mathrm{l} \mathrm{BAP}+500 \mathrm{mg} / \mathrm{l} \mathrm{CCC}+8 \%$ sucrose $)$, which was closely followed by that in $\mathrm{P}_{1}(12.7$ days) (MS $+5 \mathrm{mg} / \mathrm{l} \mathrm{BAP}+50 \mathrm{mg} / \mathrm{l}$ coumarin $+8 \%$ sucrose). Maximum number of microtubers/flask (12.8) was obtained from the protocol $\mathrm{P}_{1}$ followed by that of $\mathrm{P}_{2}(11.6)$ that contained growth retardant; but higher average weight of microtuber was obtained in the protocols $\mathrm{P}_{5}$ (30 days old plantlet + MS media containing 40 meq $\mathrm{K}+10 \mathrm{mg} / \mathrm{l} \mathrm{BA}+9 \%$ sucrose $), \mathrm{P}_{4}(\mathrm{MS}+10 \mathrm{mg} / \mathrm{BA}+8 \%$ sucrose $)$, and $\mathrm{P}_{3}(\mathrm{MS}+5.0 \mathrm{mg} / \mathrm{l} \mathrm{BAP}+$ $6 \%$ sucrose) which contained $\mathrm{BA}$ in absence of growth retardant. The average weight of microtuber was the highest $(329.0 \mathrm{mg})$ in protocol $\mathrm{P}_{5}$, followed by that in $\mathrm{P}_{4}(280.7 \mathrm{mg})$, while it was the lowest in protocol $\mathrm{P}_{1}$. The variety Diamant produced maximum average weight of microtuber $(246.3 \mathrm{mg})$, while Heera produced minimum $(226.1 \mathrm{mg})$, which was statistically similar to Cardinal $(228.7 \mathrm{mg})$. The highest percentage $(52.2)$ of $>300 \mathrm{mg}$ size and lowest percentage (19.3) of $<150 \mathrm{mg}$ size microtuber was produced in $\mathrm{P}_{5}$ protocol in the variety Diamant. On overall consideration, all the varieties performed best with the protocol $\mathrm{P}_{5}$
\end{abstract}

Keywords: Protocol, microtuber, potato.

\section{Introduction}

Micropropagation systems through node and shoot culture and in vitro tuberization have enabled maintenance and propagation of disease-free planting materials in the laboratory for the potato breeder and farmer. Both shoot and in vitro tuberization systems are advantageous because of maintenance of diseasefree materials. Moreover, in vitro tuberization of potato in the laboratory helps produce planting materials which are convenient to handle in transport, storage, and field planting. There are several published protocols for in vitro tuberization in potato (Kim, 1982; Wang and Hu, 1982; Hussey and Stacey, 1984; Tovar et al., 1985). In general, there are two basic stages in all protocols. The first stage

\footnotetext{
${ }^{1}$ Associate Professor, Department of Horticulture, Bangabandhu Sheikh Mujibur Rahman Agricultural University (BSMRAU), Gazipur, ${ }^{2}$ Professor, Department of Horticulture, BSMRAU, Gazipur, ${ }^{3}$ Professor, Department of Genetics and Plant Breeding, BSMRAU, Gazipur, ${ }^{4}$ Professor, Department of Crop Botany, BSMRAU, Gazipur, Bangladesh.
} 
aims to produce vegetative growth and the second stage to induce tuberization and allow enlargement of the tuberlets. Different authors recommended different media for vegetative multiplication and tuberization. Tovar et al. (1985) recommended $\mathrm{MS}+0.5 \mathrm{mg} / \mathrm{l} \mathrm{BAP}+0.4 \mathrm{mg} / \mathrm{l} \mathrm{GA}+0.01 \mathrm{mg} / \mathrm{l} \mathrm{NAA}+2 \%$ sucrose for the propagation phase and MS $+5.0 \mathrm{mg} / \mathrm{l} \mathrm{BAP}+500 \mathrm{mg} / \mathrm{l} \mathrm{CCC}+8 \%$ sucrose for the tuberization phase, which was useful for over 50 different genotypes covering a wide genetic base and ploidy levels and found 10 microtubers per flask having a weight of 49.8 to $143.5 \mathrm{mg}$. Wang and $\mathrm{Hu}$ (1982) obtained microtubers having an average weight of $250 \mathrm{mg}$ in $\mathrm{MS}+10.0 \mathrm{mg} / \mathrm{l}$ BAP $+8.0 \%$ sucrose while Hussey and Stacey (1984) found microtubers having a weight of 60 to $120 \mathrm{mg}$ by using $\mathrm{MS}+2.0 \mathrm{mg} / \mathrm{l} \mathrm{BAP}+6.0 \%$ sucrose. Kim (1982) induced 1-2 microtubers per node in MS + 5.0 mg/l BAP + 6\% sucrose. It is clear that microtuber number and average weight varied among protocols. The discrepancies between these findings are probably due to the use of different genotypes (Coleman and Coleman, 2000; Zakaria et al., 2008a) different mixtures of nutrient salts, and/or different concentrations of the growth regulators added (Zakaria et al., 2008b), together with possible variation in the size of vessel, light intensity and temperature. Therefore, the present study was undertaken to evaluate the performance of different protocols on in vitro tuberization in different potato varieties and to find out variety specific protocols.

\section{Meterials and Method}

In vitro grown microplants of three recommended potato cultivars viz., Cardinal, Diamant and Heera were used in the study. The microplants were multiplied through subculture of single stem nodes at every three weeks interval in Tissue culture laboratory of Horticulture Department, Bangabandhu Sheikh Mujibur Rahman Agricultural University. The experiment was carried out during the period from July to September 2008. The propagation media used for different protocols are mentioned in the Table 1 . All the propagation media were solidified with $0.8 \%$ agar. Temperature of the growth chamber was maintained at $23 \pm 1^{\circ} \mathrm{C}$ with 16 hours photoperiod at 3000 lux intensity from fluorescent tubes. At first phase, microplants were multiplied in solid media and then these were transferred into liquid media for microtuberization. Eight stem segments (Each with 3 nodes) of 30 days old in vitro microplants of Cardinal, Diamant, and Heera were cultured in $250 \mathrm{ml}$ Erlenmeyer flasks containing $40 \mathrm{ml}$ microtuber induction liquid medium, which was based on MS medium supplemented as per different protocols as shown in Table 2. The cultures were incubated in the dark at $20^{\circ} \mathrm{C}$ in continuous dark. The experiment included five protocols and three recommended potato varieties which in combination made 15 treatment combinations. The experiment was laid out in a factorial Completely Randomized Design (CRD) with three replications. The induced microtubers were harvested aseptically after 70 days of incubation. The collected data were 
analyzed with the help of computer using MSTAT-C programme and the mean separation was done by Duncan's New Multiple Range Test.

Table 1. Propagation media for in vitro multiplication of plantlet in potato.

\begin{tabular}{|c|c|c|}
\hline Media code & Media composition & Reference \\
\hline DOD & $\begin{array}{l}\text { MS (Murashige and Skoog, 1962) + GA } 0.4 \mathrm{mg} / \mathrm{l}+ \\
\text { BAP } 0.5 \mathrm{mg} / \mathrm{l}+\text { NAA } 0.01 \mathrm{mg} / \mathrm{l}+2.5 \% \text { sucrose }\end{array}$ & Dodds, et al., 1988 \\
\hline CIP & $\begin{array}{l}\mathrm{MS}+\mathrm{GA} 0.4 \mathrm{mg} / 1+\mathrm{BAP} 0.5 \mathrm{mg} / 1+\mathrm{NAA} 0.01 \\
\mathrm{mg} / \mathrm{l}+2 \% \text { sucrose }\end{array}$ & Tovar et al., 1985 \\
\hline KIM & $\begin{array}{l}\mathrm{MS}+0.1 \mathrm{mg} / \mathrm{l} \mathrm{GA}+0.5 \mathrm{mg} / \mathrm{l} \text { Kinetin }+2 \% \\
\text { sucrose. }\end{array}$ & Kim, 1982 \\
\hline SAR & $\begin{array}{l}\mathrm{MS}+0.1 \mathrm{mg} / \mathrm{l} \mathrm{GA}+0.01 \mathrm{mg} / \mathrm{l} \mathrm{NAA}+4 \mathrm{mg} / \mathrm{l} \\
\text { Calcium pantathonate }+3 \% \text { sucrose. }\end{array}$ & Sarkar et al., 1997 \\
\hline
\end{tabular}

Table 2. Different tuberization protocols of potato.

\begin{tabular}{|c|c|c|}
\hline Protocol code & $\begin{array}{l}\text { Propagation } \\
\text { medium code }\end{array}$ & Tuberization media \\
\hline $\mathrm{P}_{1}$ & DOD & $\begin{array}{l}\mathrm{MS}+5 \mathrm{mg} / \mathrm{l} \mathrm{BAP}+50 \mathrm{mg} / \mathrm{l} \text { coumarin }+8 \% \text { sucrose } \\
\text { (Dodds } \text { et al., 1988). }\end{array}$ \\
\hline $\mathrm{P}_{2}$ & CIP & $\begin{array}{l}\mathrm{MS}+5 \mathrm{mg} / \mathrm{l} \mathrm{BAP}+500 \mathrm{mg} / \mathrm{l} \mathrm{CCC}+8 \% \text { sucrose } \\
\text { (Tovar } \text { et al., 1985). }\end{array}$ \\
\hline $\mathrm{P}_{3}$ & KIM & $\mathrm{MS}+5.0 \mathrm{mg} / \mathrm{l} \mathrm{BAP}+6 \%$ sucrose, $(\mathrm{Kim}, 1982)$ \\
\hline $\mathrm{P}_{4}$ & SAR & MS + 10 mg/l BA + 8\% sucrose (Naik et al., 1998) \\
\hline $\mathrm{P}_{5}$ & SAR & $\begin{array}{l}\text { MS with } 60 \text { meq N \& } 40 \text { meq } \mathrm{K}+10 \mathrm{mg} / \mathrm{l} \mathrm{BA}+9 \% \\
\text { sucrose (Zakaria, 2003) }\end{array}$ \\
\hline
\end{tabular}

\section{Results and Discussion}

Performance of protocols: Tuberization was the earliest (11.8 days) with $\mathrm{P}_{2}$ (CIP) protocol closely followed by $\mathrm{P}_{1}$ (Table 3 ). Tuberization was most delayed (15.9 days) with $\mathrm{P}_{3}$ protocol. Rapid tuberization with $\mathrm{P}_{2}$ protocol might be due to the presence of optimum concentrations of BA and $\mathrm{CCC}$ in the medium. Microtuberization promoted in presence of CCC (Hossain and Sultana, 1998; Zakaria et al., 2008b) and BA (Islam, 1995 and Zakaria et al., 2008b). Protocol $\mathrm{P}_{5}$ showed earlier tuberization than $\mathrm{P}_{3}$ which may be due to the presence of high concentration of BA and sucrose. Such a result was also reported by Palmer and Smith (1969) and Wang and $\mathrm{Hu}$ (1982). The maximum number of microtubers/flask (12.8) was with protocol $\mathrm{P}_{1}$ closely followed by $\mathrm{P}_{2}(11.6)$. The minimum number of tubers/flask was with $\mathrm{P}_{3}$ (9.9). The protocols $\mathrm{P}_{1}$ and $\mathrm{P}_{2}$ showed higher number of microtubers per flask because of the presence of 50 $\mathrm{mg} / \mathrm{l}$ coumarin and $500 \mathrm{mg} / \mathrm{l} \mathrm{CCC}$, respectively. More number of microtubers was reported with $50 \mathrm{mg} / \mathrm{l}$ coumarin (Dodds et al., 1988) and with $500 \mathrm{mg} / \mathrm{l} \mathrm{CCC}$ 
(Hossain and Sultana, 1998). Coumarin at the rate of $50 \mathrm{mg} / \mathrm{l}$ produced more number of microtubers than $500 \mathrm{mg} / \mathrm{l}$ CCC (Dodds et al., 1988) which corroborate with the present findings. The average weight of microtuber was the highest $\left(329.0 \mathrm{mg}\right.$ ) with $\mathrm{P}_{5}$ protocol, which was closely followed by $\mathrm{P}_{4}(280.7$ $\mathrm{mg}$ ), while it was the lowest with $\mathrm{P}_{1}$ protocol. The protocol $\mathrm{P}_{5}$ produced the highest average weight of microtuber might be due to the presence of high concentrated BA $(10 \mathrm{mg} / \mathrm{l})$ and sucrose $(9 \%)$. High concentration of BA in presence of high concentration of sucrose showed best performance in micro tuberization (Texeira and Pinto, 1991 and Naik et al., 1998). The heaviest microtuber with $10 \mathrm{mg} / \mathrm{l} \mathrm{BA}$ (Teixeira and Pinto, 1991) and with 9\% sucrose was reported by Jeoung-Lai et al. (1996). Production of lower weight of microtubers by protocols $\mathrm{P}_{1}$ and $\mathrm{P}_{2}$ might be due to presence of growth retardant (Dodds et al., 1988; Harvey et al., 1991 and Lian-Yong et al., 1996). The highest percentage (44.6) of large size (>300 mg) microtuber was produced with protocol $\mathrm{P}_{5}$ followed by $\mathrm{P}_{4}(29.3 \%)$, while in $\mathrm{P}_{1}$, no large sized microtubers were produced. The maximum percentage (45.4) of $<150 \mathrm{mg}$ size microtubers was found with $\mathrm{P}_{1}$. Dodds et al. (1988) found very small $(<100 \mathrm{mg})$ microtubers with $\mathrm{P}_{1}$ protocol. Tovar et al.(1985) also reported small microtubers $(<150 \mathrm{mg})$ with $\mathrm{P}_{2}$ protocol. Wang and $\mathrm{Hu}$ (1982) found the highest microtuber by using $10 \mathrm{mg} / \mathrm{l}$ BA in combination with $8 \%$ sucrose.

Table 3. Effect of protocols on induction and development of potato microtuber.

\begin{tabular}{c|c|c|c|c|c|c}
\hline Protocols & $\begin{array}{c}\text { Days to } \\
\text { tuber }\end{array}$ & $\begin{array}{c}\text { No. of } \\
\text { microtubers/ } \\
\text { initiation }\end{array}$ & $\begin{array}{c}\text { Av. wt of } \\
\text { microtuber } \\
(\mathrm{mg})\end{array}$ & \multicolumn{3}{|c}{$\begin{array}{c}\text { Grade of microtubers by number } \\
(\%)\end{array}$} \\
\cline { 5 - 7 } & $12.7 \mathrm{c}$ & $12.8 \mathrm{a}$ & $157.4 \mathrm{e}$ & 45.4 & 54.6 & 0 \\
$\mathrm{P}_{1}$ & $11.8 \mathrm{c}$ & $11.6 \mathrm{~b}$ & $177.5 \mathrm{~d}$ & 44.3 & 52.0 & 3.7 \\
$\mathrm{P}_{2}$ & $15.9 \mathrm{a}$ & $9.9 \mathrm{~d}$ & $223.9 \mathrm{c}$ & 32.4 & 48.2 & 19.5 \\
$\mathrm{P}_{3}$ & $14.9 \mathrm{ab}$ & $10.4 \mathrm{c}$ & $280.7 \mathrm{~b}$ & 27.0 & 43.7 & 29.3 \\
$\mathrm{P}_{4}$ & $14.2 \mathrm{~b}$ & $10.9 \mathrm{c}$ & $329.0 \mathrm{a}$ & 21.3 & 34.0 & 44.6 \\
$\mathrm{P}_{5}$ & $* *$ & $* *$ & $* *$ & $\mathrm{NA}$ & $\mathrm{NA}$ & $\mathrm{NA}$ \\
\hline $\begin{array}{c}\text { Level of } \\
\text { significance }\end{array}$ & & & & & \\
$\mathrm{CV}(\%)$ & 3.57 & 3.14 & 2.16 & - & - & - \\
\hline
\end{tabular}

Means bearing same letter (s) in the same column do not differ significantly at $1 \%$ level of probability. NA- Not analyzed

Performance of potato variety: Microtuber initiation was most delayed (15.1 days) in the variety Diamant, while it was most rapid (12.3 days) in Heera (Table 4). This finding is consistent with the normal behaviour of potato cultivar in the field condition where tuberization occurs earlier in Heera than in Cardinal and Diamant (Rashid, 1999). Islam (1995) reported that microtuber initiation time 
varied with genotype. He found earlier microtuber initiation with exotic varieties (Cardinal, Kufri Shindhuri) compared to local varieties of potato. Statistically similar numbers of microtuber per flask were observed with Cardinal and Diamant. The minimum number of microtubers was found with Heera. Varietal differences on the number of microtubers were found by Islam (1995) who reported that the local varieties of potato produced poor number of microtubers compared to exotic varieties. Hossain and Sultana (1998) also found that the variety Chamak produced very poor number of microtubers compared to Patrones. Average weight of microtuber was the highest $(246.3 \mathrm{mg}$ ) in Diamant (Table 4). The minimum average weight of microtuber was shown by Heera, which was statistically similar to Cardinal. Genotypic variation on average weight of microtuber was observed by Islam (1995) who reported that the exotic varieties of potato produced higher average weight of microtuber than local varieties. Hossain and Sultana (1998) found that the variety Patrones produced significantly heavier microtuber compared to Lalsheel and Chamak. The highest percentage (22.0) of $>300 \mathrm{mg}$ size microtuber was produced by Diamant, while it was minimum in Heera (17.1\%). Cardinal produced maximum percentage (35.7) of $<150 \mathrm{mg}$ size microtuber followed by Heera (34.2\%) and Diamant (32.4\%).

Table 4. Effect of variety on induction and development of potato microtuber.

\begin{tabular}{|c|c|c|c|c|c|c|}
\hline \multirow[t]{2}{*}{ Variety } & \multirow{2}{*}{$\begin{array}{l}\text { Days to } \\
\text { tuber } \\
\text { initiation }\end{array}$} & \multirow{2}{*}{$\begin{array}{c}\text { No. of } \\
\text { microtubers/ } \\
\text { flask }\end{array}$} & \multirow{2}{*}{$\begin{array}{l}\text { Av. wt of } \\
\text { microtuber } \\
(\mathrm{mg})\end{array}$} & \multicolumn{3}{|c|}{$\begin{array}{c}\text { Grade of microtubers by number } \\
(\%)\end{array}$} \\
\hline & & & & $<150 \mathrm{mg}$ & $150-300 \mathrm{mg}$ & $>300 \mathrm{mg}$ \\
\hline Cardinal & $14.3 \mathrm{~b}$ & $11.5 \mathrm{a}$ & $228.7 \mathrm{~b}$ & 35.7 & 45.2 & 19.1 \\
\hline Diamant & $15.1 \mathrm{a}$ & $11.9 \mathrm{a}$ & $246.3 \mathrm{a}$ & 32.4 & 45.6 & 22.0 \\
\hline Heera & $12.3 \mathrm{c}$ & $9.9 \mathrm{~b}$ & $226.1 \mathrm{~b}$ & 34.2 & 48.7 & 17.1 \\
\hline $\begin{array}{c}\text { Level of } \\
\text { significance }\end{array}$ & $* *$ & $* *$ & $* *$ & NA & NA & NA \\
\hline $\mathrm{CV}(\%)$ & 3.57 & 3.14 & 2.16 & - & - & - \\
\hline
\end{tabular}

Means bearing same letter (s) in the same column do not differ significantly at $1 \%$ level of probability. NA- Not analyzed.

Interaction effect of protocols and variety: The protocol $\mathrm{P}_{2}$ followed by $\mathrm{P}_{1}$ enhanced tuber initiation in all the varieties (Table 5). Tuber initiation was most delayed (17.3 days) with protocol $\mathrm{P}_{3}$ in Diamant. Hossain and Sultana (1998) found that the tuberization was earlier with $5 \mathrm{mg} / \mathrm{l} \mathrm{BA}+500 \mathrm{mg} / \mathrm{l} \mathrm{CCC}$ irrespective of genotypes which corroborates the present findings. The highest number of microtubers (13.7) was produced with $\mathrm{P}_{1}$ protocol in Diamant. The lowest number of microtubers per flask was produced by $\mathrm{P}_{3}$ protocol in case of all varieties. Hossain and Sultana (1998) found maximum number of microtubers per plant with $5 \mathrm{mg} / \mathrm{l} \mathrm{BAP}+500 \mathrm{mg} / \mathrm{lCC}$, which was similar to the 
Table 5. Interaction effect of protocols and potato varieties on induction and development of microtuber.

\begin{tabular}{|c|c|c|c|c|c|c|c|}
\hline \multirow{2}{*}{\multicolumn{2}{|c|}{$\begin{array}{c}\text { Treatment } \\
\text { combination } \\
\text { Protocol } \times \text { Variety }\end{array}$}} & \multirow{2}{*}{$\begin{array}{l}\text { Days to } \\
\text { tuber } \\
\text { initiation }\end{array}$} & \multirow{2}{*}{$\begin{array}{l}\text { No. of } \\
\text { microtubers/ } \\
\text { flask }\end{array}$} & \multirow{2}{*}{$\begin{array}{l}\text { Average wt } \\
\text { of } \\
\text { microtubers } \\
(\mathrm{mg})\end{array}$} & \multicolumn{3}{|c|}{$\begin{array}{c}\text { Grade of microtubers by } \\
\text { number }(\%)\end{array}$} \\
\hline & & & & & $\begin{array}{c}<150 \\
\mathrm{mg}\end{array}$ & $\begin{array}{c}150-300 \\
\mathrm{mg}\end{array}$ & $\begin{array}{c}>300 \\
\mathrm{mg}\end{array}$ \\
\hline \multirow[t]{3}{*}{$P_{1} \quad X$} & Cardinal & $12.7 \mathrm{de}$ & $13.0 \mathrm{ab}$ & $145.1 \mathrm{j}$ & 45.7 & 54.3 & 0 \\
\hline & Diamant & $13.3 \mathrm{~d}$ & $13.7 \mathrm{a}$ & $162.1 \mathrm{i}$ & 46.7 & 53.3 & 0 \\
\hline & Heera & $12.0 \mathrm{ef}$ & 11.7cde & $165.0 \mathrm{i}$ & 43.8 & 56.2 & 0 \\
\hline \multirow[t]{3}{*}{$\mathrm{P}_{2}$} & Cardinal & $11.3 \mathrm{f}$ & $12.0 \mathrm{~cd}$ & $160.3 \mathrm{i}$ & 51.6 & 48.4 & 0 \\
\hline & Diamant & $12.7 \mathrm{de}$ & $12.3 b c$ & $171.3 \mathrm{i}$ & 42.1 & 57.9 & 0 \\
\hline & Heera & $11.3 \mathrm{f}$ & $10.3 \mathrm{gh}$ & $201.4 \mathrm{~h}$ & 39.2 & 49.8 & 11 \\
\hline \multirow[t]{3}{*}{$\mathrm{P}_{3}$} & Cardinal & $16.7 \mathrm{ab}$ & $10.3 \mathrm{gh}$ & $216.2 \mathrm{~g}$ & 32.3 & 47.1 & 20.6 \\
\hline & Diamant & $17.3 \mathrm{a}$ & $10.7 \mathrm{fg}$ & $235.3 \mathrm{f}$ & 29.4 & 49.1 & 21.5 \\
\hline & Heera & $13.3 \mathrm{~d}$ & $8.7 \mathrm{j}$ & $220.2 \mathrm{~g}$ & 35.4 & 48.3 & 16.3 \\
\hline \multirow[t]{3}{*}{$\mathrm{P}_{4}$} & Cardinal & $15.7 b c$ & 11.0efg & $285.4 d$ & 28.1 & 45.2 & 26.7 \\
\hline & Diamant & $16.6 a b$ & 11.3def & $297.4 \mathrm{c}$ & 24.2 & 39.3 & 36.5 \\
\hline & Heera & 12.3def & $9.0 \mathrm{ij}$ & $259.4 \mathrm{e}$ & 28.7 & 46.6 & 24.7 \\
\hline \multirow[t]{3}{*}{$\mathrm{P}_{5}$} & Cardinal & $15.0 \mathrm{c}$ & $11.3 \mathrm{def}$ & $336.5 b$ & 20.6 & 31.2 & 48.2 \\
\hline & Diamant & $15.7 \mathrm{bc}$ & 11.7cde & $365.5 \mathrm{a}$ & 19.3 & 28.5 & 52.2 \\
\hline & Heera & 12.0ef & $9.6 \mathrm{i}$ & $285.1 d$ & 24.1 & 42.4 & 33.5 \\
\hline \multicolumn{2}{|c|}{ Level of significance } & $* *$ & $* *$ & $* *$ & NA & NA & NA \\
\hline \multicolumn{2}{|c|}{$\mathrm{CV}(\%)$} & 3.57 & 3.14 & 2.16 & - & - & - \\
\hline
\end{tabular}

Means bearing same letter (s) in the same column do not differ significantly at $1 \%$ level of probability. NA- Not analyzed.

performance of $\mathrm{P}_{2}$ protocol. Dodds et al. (1988) found more number of microtubers by using $50 \mathrm{mg} / \mathrm{l}$ coumarin $\left(\mathrm{P}_{1}\right)$ instead of $500 \mathrm{mg} / \mathrm{l} \mathrm{CCC}\left(\mathrm{P}_{2}\right)$. The protocol $\mathrm{P}_{5}$ produced the highest $(365.5 \mathrm{mg})$ average weight of microtuber in the variety Diamant (Table 5). Lower average weight of microtuber was with $P_{1}$ and $\mathrm{P}_{2}$ protocol in all varieties. Lower microtuber weight might be due to the presence of growth retardant which reduced microtuber weight (Harvey et al.,1991; Leclerc et al., 1994 and Lian-Yong et al., 1996). Higher microtuber weight with $\mathrm{P}_{5}$ and $\mathrm{P}_{4}$ was obviously due to the presence of high concentration of BA and sucrose (Koda and Okazawa, 1983; Wang and Hu, 1982, and Palmar and Smith, 1969). The highest percentage (52.2) of $>300 \mathrm{mg}$ size and lowest percentage (19.3) of $<150 \mathrm{mg}$ size microtuber was produced with $\mathrm{P}_{5}$ protocol in Diamant variety of potato (Table 5). In case of all varieties, the protocol $P_{1}$ did not produce any microtuber of size $>300 \mathrm{mg}$, while $\mathrm{P}_{2}$ produced the highest percentage (51.6) of $<150 \mathrm{mg}$ size microtuber in Cardinal. 


\section{References}

Coleman, W. K. and S. E. Coleman. 2000. Modification of potato microtuber dormancy during induction and growth in vitro or ex vitro. Amer. J. Potato Res. 77: 103-110.

Dodds, J. H., P. Tovar, R. Chandra, D. Estrella and R. Cabello. 1988. Improved methods for in vitro tuber induction and use of in vitro tubers in seed programs. In: Proc. Symp. on Improved Potato Planting Meterial, Kunming, China, June 21-24, 1988. Asian Potato Assoc. Pp. 157-158.

Harvey, B. M. R., S. H. Crothers, N. E. Evans and C. Selby. 1991. The use of growth retardants to improve microtuber formation by potato. Plant Cell Tiss. Org. Cult. 27: $59-64$.

Hossain M. J. and N. Sultana. 1998. Effect of Benzylamino purine (BAP) and chloro choline choride (CCC) on in vitro tuberisation of potato. Bangladesh J. Agril. Res. 23(4): 685-690.

Hussey, G. and N. J. Stacey. 1984. Factors affecting the formation of in vitro tubers of potato (Solanum tuberosum L.). Ann. Bot. 53: 565-578.

Islam, M. S. 1995. Indigenous potato varieties of Bangladesh: Characterization by RAPD markers and production of virus free stock. Ph. D. Dissertation. Submitted to Dept. of Horticulture, Bangabandhu Sheikh Mujibur Rahman Agricultural University, Gazipur-1706. Bangladesh.

Jeoung-Lai, C., S. M. Kang and Y. W. Choi. 1996. Effect of shoot culture and tuber inducing conditions on in vitro tuberization of potatoes. Proceedings of the fourth Asian Potato Association Triennial Conference. Philippines. Pp. 186-190.

Kim, Y. C. 1982. In vitro tuber formation from proliferated shoots of potato (Solanum tuberosum) as a method of aseptic maintenance, Ph. D. Dissertation, South Korea. In: P. Tovar, R. Eatrada, L. Schilde-Rentschler and J. H. Dodds. 1985. Induction and use of in vitro tubers. CIP Circular 13(4): 1-5.

Koda, Y. and Y. Okazawa. 1983. Influences of environmental, hormonal and nutritional factors on potato tuberization in vitro. Jpn. J. Crop Sci. 52: 582-591.

Leclerc, Y., D. J. Donnely and J. E. A. Seabrook. 1994. Microtuberization of layered shoots and nodal cuttings of potato: The influence of growth regulators and incubation periods. Plant Cell Tiss. Org.Cult. 37(2): 113-120.

Lian-Yong, D. Huiruo, X. Xin, Y. Hongfu, J. Liping, L. Huan and Z. Ying. 1996. Changes of several endogenous phytohormones during in vitro tuberization in potato. In : E. T. Rasco and F. B. Aromin (eds.). Asian Sweetpotato and Potato Research and Development, Manila. Selected Research Papers. July 1995-June 1996. Vol. 1: Potato P. 30-37.

Murashige, T. and F. Skoog, 1962. A revised medium for rapid growth and bioassays with tobacco tissue cultures. Physiologia Plantarum 15: 473-497.

Naik, P. S., D. Sarkar and P. C. Gaur 1998. Yield components of potato microtubers in vitro production and field performance. Ann. Appl. Biol. 133: 91-99. 
Plamer, C. E. and O. E. Smith. 1969. Cytokinins and tuber initiation in the potato (Solanum tuberosum L.). Nature 221: 279-280.

Rashid, M. M. 1999. Shabjee Bighan. Rashid Publishing House, 94 old DOHS, Dhaka. Pp. 129-161.

Sarkar, D., R. Chandra and P. S. Naik, 1997. Effect of inoculation density on potato micropropagation. Plant Cell Tiss. Org. Cult. 48: 63-66.

Teixeira, D.M.C. and J.E.B.P. Pinto. 1991. Minituberization of potatoes at different levels of N, saccharose and BAP. Revista-Brasileria-de-Fisiologia-Vegetal 3(3). 77-83.

Tovar, P., R. Estrada, L. Schilde-Rentschler and J. H. Dodds, 1985. Induction of in vitro potato tubers. CIP Circular 13: 1-4.

Wang, P. J. and C. Y. Hu. 1982. In vitro mass tuberisation and virus-free seed potato production in Taiwan. Amer. J. Potato Res. 59: 33-37.

Zakaria, M. 2003. Induction and performance of potato microtuber. Ph. D. Dissertation, Dept. of Horticulture. Bangabandhu Sheikh Mujibur Rahman Agricultural University, Gazipur-1706, Bangladesh. 182P.

Zakaria, M., M. M. Hossain, M. A. Khaleque Mian, T. Hossain and M. Z. Uddin. 2008a. Role of sucrose in micro tuberization in potato. Bangladesh J. Agril. Res. 33(1): 91-97.

Zakaria, M., M. M. Hossain, M. A. Khaleque Mian, T. Hossain and M. Z. Uddin. 2008b. In vitro tuberization of potato influenced by benzyl adenine and chlorocholine chloride. Bangladesh J. Agril. Res. 33(3): 419-425. 